\title{
PERAN PEMERIKSAAN ELEKTROFISIOLOGI DALAM DIAGNOSIS SINDROM MILLER-FISHER
}

\author{
Ahmad Asmedi ${ }^{1}$, Sekar Satiti ${ }^{1}$, Lothar Matheus Manson Vanende Silalahi ${ }^{2}$ \\ ${ }^{1}$ Departemen Neurologi, FK-KMK Universitas Gadjah Mada/RSUP Dr. Sardjito, Yogyakarta, Indonesia \\ ${ }^{2}$ Departemen Neurologi, FK Universitas Kristen Duta Wacana, Yogyakarta, Indonesia
}

Diterima 12 Desember 2019

Disetujui 23 Maret 2020

Publikasi 10 Juni 2020

Korespondensi: ahmad.asmedi@ugm.ac.id
Cara merujuk artikel ini: Sanyasi (et al). 2020. Peran pemeriksaan elektrofisiologi dalam diagnosis sindrom miller-fisher. Callosum Neurology Journal 3(2): 71-77. DOI: https://doi.org/10.29342/cnj.v3i2.60

\begin{abstract}
ABSTRAK
Latar Belakang: Sindrom Miller-Fisher merupakan salah satu varian Sindrom Guillain-Barre yang memiliki trias klasik yaitu optalmoplegia, ataksia, dan juga arefleksia. Pemeriksaan penunjang pada Sindrom Miller-Fisher berperan penting karena beberapa penyakit juga bermanifestasi seperti trias klasik tersebut.

Tujuan: Membahas peran pemeriksaan elektrofisiologi dalam diagnosis Sindrom Miller-Fisher.

Diskusi: Hasil studi menunjukkan abnormalitas amplitudo Sensory Nerve Action Potential (SNAP) dan H-reflex secara konsisten terjadi pada Sindrom Miller-Fisher.
\end{abstract}

Abnormalitas tersebut reversibel dan akan cepat membaik sehingga pemeriksaan elektrofisiologi serial diperlukan untuk menunjang diagnosis. Temuan tersebut diperkuat dengan hasil pemeriksaan konduksi saraf motorik, konduksi saraf sensorik dan F-wave yang normal.

Simpulan: Pemeriksaan elektrofisiologi menunjang diagnosis serta dapat menjelaskan proses penyakit Sindrom Miller-Fisher.

Kata Kunci: Sindrom Miller-Fisher, elektrofisiologi, diagnosis

\begin{abstract}
Background: Miller-Fisher Syndrome is one of GuillainBarre Syndrome subtype with clinically unique classic triad of ophthalmoplegia, ataxia, and also areflexia. Additional examination become important because some disease may manifest as the classic triad of Miller-Fisher Purpose: This paper reviews the role of electrophysiological study in the diagnosis of Miller-Fisher Syndrome.

Discussion: The results of the studies showed that abnormalities in Sensory Nerve Action Potential (SNAP) amplitude and $\mathrm{H}$-reflex are consistently occurred in
\end{abstract}

Miller-Fisher Syndrome. This will improve quickly and reversibly, hence serial examination is needed to support the diagnosis. These findings can be supported with the normal result of motor conduction study, sensory conduction study, and F-wave.

Conclusion: Electrophysiological examination may support diagnosis and explain the natural process of Miller-Fisher Syndrome.

Keywords: Miller-Fisher Syndrome, electrophysiology, diagnosis 


\section{Pendahuluan}

Sindrom Miller-Fisher merupakan salah satu varian Sindrom Guillain-Barre yang memiliki gambaran klinis unik dengan trias klasik optalmoplegia, ataksia, dan arefleksia. ${ }^{1}$ Sindrom Miller-Fisher memiliki insidensi yang cukup tinggi di Asia dibandingkan Eropa. Kasus Sindrom Miller-Fisher terjadi $15-25 \%$ dari Sindrom Guillain-Barre Asia dibandingkan dengan 1-7\% di barat. $^{2}$

Diagnosis Sindrom Miller-Fisher ditegakkan berdasarkan kemunculan gejala dan tanda klinis trias klasik (optalmoplegia, ataksia, dan arefleksia) didukung dengan pemeriksaan penunjang. ${ }^{2}$ Peran pemeriksaan penunjang menjadi sangat penting karena beberapa kondisi penyakit juga dapat bermanifestasi seperti trias klasik pada Sindrom Miller-Fisher. ${ }^{3}$

Pemeriksaan elektrofisiologi pada Sindrom Miller-Fisher telah banyak dilakukan dan cukup menarik minat para peneliti karena diharapkan juga dapat membantu memberikan gambaran yang lebih jelas mengenai Sindrom MillerFisher. ${ }^{4}$ Pemeriksaan ini juga dapat menyingkirkan kemungkinan penyakit lain yang manifestasi klinisnya berupa optalmoplegia dan

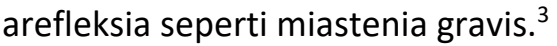

Belum terdapat konsensus secara elektrofisiologi untuk diagnosis Sindrom MillerFisher karena hasil penelitian yang ada sering kontradiktif sehingga menimbulkan kontroversi. ${ }^{5}$ Atas dasar tersebut maka perlu dibuat suatu tinjauan pustaka yang bertujuan untuk menyusun artikel-artikel yang berkaitan dengan penggunaan elektrofisologi dalam menegakkan diagnosis Sindrom Miller-Fisher.

\section{Pembahasan}

\section{Elektrofisiologi pada Sindrom Miller-Fisher}

Trias klasik Sindrom Miller-Fisher adalah optalmoplegia, arefleksia, dan ataksia, onset akut. ${ }^{2}$ Sindrom Miller-Fisher sering dimulai dengan diplopia (57\%), ataksia (32\%) atau kedua-duanya. ${ }^{4}$ Pada Sindrom Miller-Fisher, infeksi Clostridium jejuni memicu terbentuknya antibodi anti-GQ1b. ${ }^{4}$ Gangliosid GQ1b banyak terdapat pada mielin paranodal di saraf kranial III, IV dan VI. Area paranodal sangat penting dalam proses konduksi impuls saraf. ${ }^{6}$ Lokasi spesifik inilah yang menyebabkan gambaran klinis optalmoplegia pada Sindrom Miller-

Fisher. $^{2}$

Gangliosid GQ1b juga banyak terdapat pada spindel otot. Gangguan pada spindel otot ini menyebabkan terganggunya proses propriosepsi sehingga hal inilah yang menyebabkan ataksia pada Sindrom Miller-Fisher. ${ }^{2}$

Arefleksia merupakan tanda spesifik paling jarang terjadi pada trias klasik Sindrom MillerFisher. Arefleksia kemungkinan terjadi karena gangguan neuron sensorik secara selektif yang melibatkan neuron yang memediasi refleks tendon. ${ }^{1}$ Imunohistokimia menunjukkan bahwa serabut saraf besar 1a pada ganglion radiks dorsalis terwarnai oleh antibodi terhadap protein GQ1b sehingga dimungkinkan berhubungan dengan arefleksia. ${ }^{1}$

Studi elektrofisiologi yang telah banyak dilakukan pada Sindrom Miller-Fisher selama ini lebih banyak berfokus pada pemeriksaan konduksi saraf ekstremitas karena pemeriksaan elektrofisiologi untuk mengevaluasi optalmoplegia sangat terbatas. ${ }^{1}$ Parameter elektrofisiologi saraf ekstremitas yang banyak diperiksa adalah konduksi saraf motorik dan Fwave, konduksi saraf sensorik, SNAP (amplitudo dan durasi) serta H-reflex.

\section{Konduksi Saraf Motorik dan F-wave}

Pemeriksaan konduksi saraf motorik pada Sindrom Miller-Fisher pada kebanyakan kasus hasilnya normal tanpa menunjukkan kelainan. ${ }^{4}$ Ito dkk., (2008) melakukan pemeriksaan konduksi saraf motorik pada 28 pasien Sindrom Miller-Fisher. Tidak didapatkan kelainan pada nilai kecepatan hantar maupun F-wave pada seluruh pasien Sindrom Miller-Fisher pada penelitian tersebut meskipun pasien dengan kelemahan anggota gerak ringan (kekuatan otot $\geq 4$ ) ikut dalam penelitian. ${ }^{7}$

Shahrizaila dkk., (2011) mulai melakukan pemeriksaan elektrofisiologi serial pada pasien Sindrom Guillain-Barre dan Sindrom MillerFisher. $^{8}$ Dari 6 kasus Sindrom Guillain-Barre, hanya 1 pasien yang memenuhi kriteria klinis Sindrom Miller-Fisher. Pada pasien dengan Sindrom Miller-Fisher tidak didapatkan abnormalitas hasil konduksi saraf motorik maupun F-wave baik pada saat awitan penyakit maupun follow-up. ${ }^{8}$ Setelah laporan kasus tersebut, penelitian elektrofisiologi pada 
Sindrom Guillain-Barre umumnya dan khususnya pada Sindrom Miller-Fisher dilakukan secara serial.

Shiga dkk., (2012) secara retrospektif melaporkan sepuluh pasien Sindrom MillerFisher yang telah dilakukan pemeriksaan konduksi saraf motorik dan F-wave pada saraf medianus dan saraf tibialis ekstremitas kanan dengan membagi pasien tersebut menjadi dua kelompok yaitu kelompok tanpa gejala disestesia dan kelompok dengan gejala disestesia. ${ }^{9}$ Hasil pemeriksaan konduksi saraf motorik dan F-wave seluruh pasien pada kedua kelompok normal dan tidak ada perbedaan yang bermakna antara kelompok disestesia dan tanpa disestesia. ${ }^{9}$ Hasil penelitian ini juga sama seperti penelitian yang dilakukan oleh Sekiguchi dkk., (2013) yang melakukan pemeriksaan elektrofisiologi pada 47 pasien Sindrom MillerFisher dengan hasil pemeriksaan konduksi saraf motorik dan latensi $\mathrm{F}$-wave seluruh pasien dalam batas normal. ${ }^{10}$

Beberapa studi menunjukkan adanya abnormalitas namun hanya dalam derajat yang ringan. Dachy dkk., (2010) melaporkan pemeriksaan elektrofisiologi 3 pasien Sindrom Miller-Fisher pada anak-anak. Dari 3 pasien tersebut, didapatkan abnormalitas saraf motorik hanya pada 1 pasien berupa perlambatan kecepatan hantar saraf, penurunan amplitudo serta pemanjangan latensi $\mathrm{F}$-wave pada saraf medianus serta hilangnya F-wave pada saraf tibialis. ${ }^{11}$ Tidak dilakukan pemeriksaan follow-up elektrofisiologi pada pasien tersebut namun secara klinis pasien yang pada awalnya mengalami ataksia dapat berjalan dengan bantuan minimal setelah terapi imunoglobulin intravena dan metilprednisolon. ${ }^{11}$ Hasil temuan ini memiliki beberapa keterbatasan. Pertama, pemeriksaan dilakukan pada jumlah sampel yang sedikit (3 orang). Kedua, pemeriksaan elektrofisiologi hanya dilakukan satu kali tanpa follow-up. ${ }^{11}$

Umapathi dkk., (2012) melakukan pemeriksaan konduksi saraf motorik dan F-wave pada saraf medianus, ulnaris, tibialis dan peroneus pada 10 pasien Sindrom Miller-Fisher murni dan mendapatkan 2 pasien yang mengalami pemanjangan latensi distal motorik hanya pada saraf medianus. ${ }^{12}$ Pemanjangan latensi distal tersebut dalam derajat yang ringan dan kembali ke normal pada follow-up 4 minggu berikutnya. Perbaikan latensi distal motorik saraf medianus terjadi tanpa adanya tanda remielinisasi. ${ }^{12}$ Pada penelitian ini kemungkinan hasil abnormalitas pada saraf medianus karena adanya sindrom terowongan karpal yang sudah ada sebelumnya. ${ }^{12}$

Shahrizaila dkk., (2014) kembali melakukan pemeriksaan konduksi saraf motorik dan F-wave pada 11 pasien dengan klinis Sindrom MillerFisher dan mendapatkan hanya 1 pasien yang mengalami abnormalitas berupa entrapment neuropathy multipel berupa pemanjangan latensi distal dan perlambatan kecepatan hantar saraf. ${ }^{13}$ Pasien ini juga memiliki diabetes melitus sehingga peran diabetes melitus terhadap abnormalitas elektrofisiologi yang ditemukan belum dapat disingkirkan. ${ }^{13}$

Kegagalan konduksi reversibel mungkin merupakan mekanisme yang tepat terjadi pada Sindrom Miller-Fisher. ${ }^{12}$ Pola perbaikan cepat ini sesuai dengan gambaran disfungsi pada aksolema nodal dan paranodal, sama seperti proses patologis yang terjadi pada acute motor axonal neuropathy (AMAN) dan acute motor sensoric axonal neuropathy (AMSAN). Proses ini juga dapat menjelaskan perbaikan abnormalitas konduksi saraf motorik yang membaik pada lokasi-lokasi yang sering mengalami entrapment. ${ }^{12}$

Reaksi antibodi-antigen terjadi pada nodus ranvier secara transien mengganggu proses konduksi. ${ }^{14}$ Ikatan autoantibodi pada nodus ranvier ini akan mengaktifkan kaskade komplemen yang akan menghasilkan kompleks yang akan merusak membran saraf. Saluran natrium akan hilang, pelepasan mielin serta pemanjangan nodus ranvier. Hal ini yang menyebabkan abnormalistas pada amplitudo SNAP dengan kecepatan hantar saraf yang tidak terganggu. ${ }^{8}$ Saat kaskade komplemen sudah hilang, terjadi pembentukan kembali saluran natrium dan fungsi nodus ranvier akan kembali normal. ${ }^{15}$

Hipotesis ini didukung dengan suatu biopsi pada saraf suralis yang menunjukkan adanya pemanjangan nodus ranvier dan pemisahan neuron tanpa adanya gambaran demielinisasi. ${ }^{1}$ Temuan ini juga menunjang adanya perbaikan klinis pada perjalanan penyakit Sindrom Miller 
Fisher seperti yang juga ditemukan pada pasien AMAN. ${ }^{1}$

\section{Sensory Nerve Action Potential (SNAP)}

Abnormalitas amplitudo SNAP merupakan hal yang cukup konsisten ditemukan pada pasien Sindrom Miller-Fisher walaupun pada beberapa penelitian bukan merupakan hasil temuan utama. ${ }^{7,10}$ Hasil ini membuktikan adanya keterlibatan serabut saraf sensorik perifer pada proses penyakit ini terutama pada serabut saraf besar bermielin. ${ }^{1,9}$ Penurunan SNAP pada beberapa studi ini masih banyak dipertanyakan karena penurunan amplitudo SNAP tidak nyata dan tidak dapat mewakili gambaran klinis ataksia yang berat pada Sindrom Miller-Fisher. ${ }^{1}$ Penelitian yang dilakukan oleh Ito pada tahun 2008 mendapatkan adanya abnormalitas amplitudo SNAP pada $2 \%$ dari 28 pasien Sindrom Miller-Fisher walaupun pada penelitian tersebut abnormalitas amplitudo SNAP bukan merupakan yang utama dijumpai. ${ }^{7}$

Penelitian yang dilakukan oleh Shahrizaila dkk., (2011) pada 1 pasien Sindrom Miller-Fisher murni, didapatkan adanya penurunan amplitudo SNAP pada awitan 3 hari gejala penyakitnya. Shahrizaila melakukan pemeriksaan serabut saraf sensoris saraf medianus, ulnaris, radialis, dan suralis secara ortodromik dan mendapatkan amplitudo SNAP mengalami penurunan pada saraf medianus, ulnaris dan suralis. ${ }^{8}$ Pada hari ke-128 setelah awitan kembali dilakukan pemeriksaan sensorik dan didapatkan amplitudo SNAP keempat saraf yang dilakukan pemeriksaan seluruhnya dalam batas normal. ${ }^{8}$

Shiga dkk., (2011) melakukan pemeriksaan amplitudo SNAP pada 10 pasien Sindrom MillerFisher dan mendapatkan bahwa terjadi penurunan amplitudo SNAP pada pasien Sindrom Miller-Fisher dibandingkan dengan kontrol normal. ${ }^{9}$ Amplitudo SNAP juga secara signifikan lebih kecil pada kelompok pasien Sindrom Miller-Fisher yang mengalami gejala disestesia dibandingkan dengan kelompok tanpa gejala disestesia. Dilakukan follow-up secara serial pada minggu pertama sampai ketiga dan minggu ke-12, didapatkan kecenderungan adanya perbaikan amplitudo setiap dilakukan pemeriksaan dan mencapai nilai amplitudo SNAP normal pada minggu ke-12 follow-up. ${ }^{9}$ Hasil ini semakin mendukung neuropati sensori pada pasien Sindrom Miller-Fisher dan derajat keparahan demielinisasi yang terjadi dapat menjelaskan ada atau tidaknya gejala sensoris subjektif yang dialami. ${ }^{9}$

Hasil yang sama juga didapatkan oleh Lyu dkk., (2013) yang menyimpulkan abnormalitas amplitudo SNAP merupakan karakteristik utama gangguan sensorik pada pasien Sindrom MillerFisher. ${ }^{14}$ Hasil menarik dari studi ini adalah amplitudo SNAP pada ekstremitas atas yang diwakili oleh saraf medianus dan ulnaris memang lebih rendah dibandingkan dengan kontrol yang normal namun tidak demikian dengan amplitudo SNAP saraf suralis yang tidak berbeda dibandingkan dengan kontrol normal. ${ }^{14}$ Hasil penelitian oleh Lyu dkk., (2008) dan Sekiguchi dkk., (2013) mendapatkan adanya pola abnormalitas amplitudo SNAP yang lebih banyak terjadi pada ekstremitas atas dibandingkan dengan ekstremitas bawah yang diistilahkan sebagai pola sural sparring. ${ }^{1} \mathrm{Hal}$ ini terjadi karena saraf medianus sensoris yang diperiksa merupakan cabang distal sementara saraf suralis merupakan cabang intermediate. ${ }^{1}$

Temuan ini memunculkan hipotesis adanya lesi pada ganglion radiks dorsalis yang menyebabkan degenerasi dying back pada akson distal terlebih dahulu sehingga menjelaskan amplitudo SNAP saraf medianus menurun sementara amplitudo SNAP saraf suralis normal. ${ }^{1}$ Ketika akson distal terganggu, pemeriksaan pada saraf medianus dan saraf ulnaris dapat dideteksi dengan mudah dibandingkan dengan saraf suralis. ${ }^{1}$

Umapathi dkk., (2012) melakukan pemeriksaan konduksi serabut saraf sensoris pada pasien dengan Sindrom Miller-Fisher dan mendapatkan bahwa terdapat 2 pasien yang mengalami penurunan amplitudo SNAP pada saraf medianus, ulnaris dan suralis. ${ }^{12}$ Selama followup terjadi perbaikan amplitudo SNAP pada satu pasien yang mulai terlihat pada minggu kedua, puncaknya pada minggu keempat dan satu pasiennya lainnya gambaran abnormalitas amplitudo SNAP cenderung menetap. Hal menarik yang didapatkan pada laporan kasus ini adalah pada 2 pasien terjadi peningkatan signifikan amplitudo SNAP selama follow-up walaupun pada saat pemeriksaan awal masih dalam rentang normal. Perbaikan amplitudo SNAP tanpa disertai dengan tanda demielinisasi dan remielinisasi maka dapat disebut sebagai 
kegagalan konduksi reversibel (reversible conduction failure). ${ }^{12}$

Sekiguchi dkk., (2013) mendapatkan bahwa amplitudo SNAP rata-rata pasien Sindrom MillerFisher lebih rendah pada saraf medianus dan ulnaris dibandingkan dengan kontrol sehat tetapi tidak didapatkan perbedaan signifikan pada amplitudo SNAP saraf suralis antara kelompok Sindrom Miller-Fisher dibandingkan dengan kontrol sehat. ${ }^{10}$

Terjadi penurunan signifikan amplitudo SNAP pada 94\% pasien Sindrom Miller-Fisher dari hasil penelitian yang dilakukan oleh Shahrizaila dkk., (2014). ${ }^{13}$ Pada follow-up terjadi peningkatan amplitudo SNAP 2 kali lipat dibandingkan awal pada $50 \%$ pasien pada minggu keempat. Pasien lainnya terjadi perbaikan amplitudo SNAP dengan pola yang lambat dan progresif seperti yang terlihat pada pola regenerasi aksonal. ${ }^{13}$

Hampir seluruh studi mendapatkan bahwa abnormalitas amplitudo SNAP yang didapatkan pada awal pemeriksaan kembali ke nilai normal pada pemeriksaan elekstrofisiologi follow-up dengan cepat tanpa ada tanda demielinisasi atau remielinisasi (temporal dispersi). Perbaikan cepat serabut sensoris ini sama seperti proses yang terjadi pada kegagalan konduksi motorik reversibel (reversible motor conduction failure). ${ }^{13}$

Sangat sedikit studi yang memberi perhatian terhadap durasi SNAP pada pemeriksaan elektrofisiologi. Shiga dkk., (2012) melakukan elektrofisiologi pada pasien Sindrom MillerFisher dengan memperhatikan parameter durasi SNAP dan membandingkan dengan kontrol yang sehat. Durasi SNAP dalam studi tersebut didefinisikan sebagai waktu yang dibutuhkan dari gelombang mulai meninggalkan garis dasar hingga puncak dari defleksi positif. ${ }^{9}$

Studi tersebut memberikan hasil bahwa pada penderita Sindrom Miller-Fisher terjadi pemanjangan durasi SNAP signifikan dibandingkan dengan kontrol sehat pada saraf suralis dan saraf medianus walaupun pada saraf medianus tidak bermakna secara statistik. ${ }^{9}$ Durasi SNAP terutama mengalami pemanjangan pada pasien Sindrom Miller-Fisher yang mengalami gejala disestesia dibandingkan dengan tanpa gejala disestesia. Pada follow-up terjadi pemendekan durasi SNAP bertahap, terlihat pada minggu kedua dan puncaknya pada minggu keempat yang kemudian berhenti ketika amplitudo SNAP mencapai nilai normal. ${ }^{9}$

Hasil ini pada dasarnya membuktikan bahwa derajat keparahan demielinisasi mempengaruhi gejala subyektif yang dirasakan. Pada pasien Sindrom Miller-Fisher yang mengalami gejala disestesia berarti keparahan demielinisasinya lebih berat sehingga terjadi pemanjangan durasi SNAP dibandingkan dengan yang tidak mengalami gejala disestesia. Pada follow-up, pemanjangan durasi SNAP ini juga membaik seiring dengan normalnya amplitudo SNAP sehingga dapat dikatakan terjadi proses patofisiologi yang sama yang melibatkan amplitudo SNAP dan durasi SNAP. ${ }^{9}$ Hasil penelitian lain yang dilakukan oleh Umapathi dkk., (2012) di mana pada 10 pasien Sindrom Miller-Fisher yang dilakukan pemeriksaan durasi SNAP, tidak ada pasien dengan hasil abnormal. ${ }^{12}$ Kecepatan hantar serabut saraf sensoris merupakan pemeriksaan yang tidak rutin dilakukan dalam elektrofisiologi tetapi beberapa studi melakukan pemeriksaan ini untuk lebih memahami proses perjalanan penyakit Sindrom Miller-Fisher. Kebanyakan laporan kasus dan penelitian tidak mendapatkan abnormalitas pada pemeriksaan kecepatan hantar serabut saraf sensoris Sindrom Miller-Fisher. ${ }^{1}$ Hanya sebagian kecil yang melaporkan abnormalitas dan terjadi pada laporan kasus dengan sampel yang sedikit. Abnormalitas kecepatan hantar saraf sensoris dilaporkan terjadi pada 1 dari 3 pasien anak-anak dengan Sindrom Miller-Fisher pada laporan kasus yang dilakukan oleh Dachy dkk., (2010) sementara pada 2 pasien lainnya didapatkan hasil normal. ${ }^{11}$

Hasil yang berbeda terjadi pada laporan kasus 10 pasien Sindrom Miller-Fisher oleh Shiga dkk., (2012) dengan hasil pemeriksaan kecepatan hantar saraf sensorik didapatkan normal. ${ }^{9}$ Shiga yang membagi kelompok penyakit Sindrom Miller-Fisher menjadi dengan disestesia dan tanpa disestesia juga tidak mendapatkan perbedaan signifikan hasil kecepatan hantar saraf sensorik antara kedua kelompok. Pemeriksaan elektrofisologi follow-up juga tidak didapatkan adanya perubahan hasil yang bermakna. ${ }^{9}$ Hasil yang serupa juga didapatkan oleh Sekiguchi dkk., (2013) yang melakukan pemeriksaan elektrofisologi pada 47 pasien 
sindrom Miller-Fisher dan membandingkan hasilnya dengan pasien normal. ${ }^{10}$

\section{H-reflex}

Hilangnya H-reflex merupakan temuan abnormalitas yang reliabel dan paling konsisten pada pasien Sindrom Miller-Fisher. ${ }^{7,10}$ Pemeriksaan H-reflex dikatakan menghilang apabila tidak terdapat respon munculnya gelombang $\mathrm{H}$ dan $\mathrm{H}$-reflex dikatakan menurun apabila rasio amplitudo gelombang $\mathrm{H}$ dengan gelombang $\mathrm{M}$ (rasio $\mathrm{H} / \mathrm{M}$ ) < 3\%. Amplitudo gelombang $\mathrm{H}$ dan gelombang $\mathrm{M}$ yang diambil merupakan amplitudo tertinggi yang didapatkan pada saat pengukuran. ${ }^{10}$

Dachy dkk., (2010) menyebutkan bahwa hilangnya $\mathrm{H}$-Reflex dapat dijadikan salah satu pendekatan diagnosis Sindrom Miller-Fisher. ${ }^{11}$ Dari 3 pasien anak yang mengalami Sindrom Miller-Fisher didapatkan bahwa keseluruhan pasien mengalami hilangnya $\mathrm{H}$-Reflex. ${ }^{11}$

Hasil studi tersebut mendukung hasil penelitian sebelumnya yang dilakukan oleh Ito dkk., (2008) yang mendapatkan bahwa kelainan elektrofisiologi berupa hilangnya $\mathrm{H}$-Reflex paling banyak dijumpai pada pasien Sindrom MillerFisher. Studi tersebut mendapatkan menghilangnya H-Reflex didapatkan pada $74 \%$ pasien Sindrom-Miller Fisher. ${ }^{7}$

Penelitian oleh Sekiguchi dkk., (2013) juga mendapatkan hasil yang hampir sama. Dari 47 pasien Sindrom Miller-Fisher yang diperiksa $\mathrm{H}$ Reflex, 67\% pasien mengalami abnormalitas $\mathrm{H}$ Reflex. ${ }^{10}$ Abnormalitas yang terjadi berupa hilangnya $\mathrm{H}$-Reflex (56\%) dan menurunnya $\mathrm{H}$ Reflex (15\%). Dari studi tersebut disimpulkan bahwa hilangnya H-Reflex pada pemeriksaan elektrofisiologi merupakan abnormalitas yang paling sering ditemui pada pasien Sindrom Miller-Fisher. ${ }^{10}$

Hilang atau abnormalitas H-reflex merupakan hasil yang konsisten pada banyak penelitian dan merupakan temuan yang utama.,10 Abnormalitas H-reflex merefleksikan lesi spesifik pada neuron 1a pada ganglion radiks dorsalis dan juga berperan dalam terjadinya ataksia dan arefleksia pada Sindrom Miller-Fisher. ${ }^{1}$

Studi imunohistokimia lain telah menunjukkan bahwa protein GQ1b juga terekspresi spindel otot tungkai manusia sehingga beberapa peneliti telah menyimpulkan bahwa kemungkinan klinis ataksia dan arefleksia pada Sindrom MillerFisher juga disebabkan karena abnormalitas spindel otot. ${ }^{1}$ Pernyataan ini belum dapat sepenuhnya diterima karena secara elektrofisiologi pemeriksaan H-reflex dilakukan dengan stimulasi saraf tibialis sehingga tidak mewakili spindel otot. ${ }^{10}$

\section{Pemeriksaan Elektrofisiologi Lain}

Beberapa studi juga melakukan pemeriksaan elektrofisiologi lain seperti EMG, blink reflex, transcranial magnetic stimulation (TMS), posturography, dan somatosensory-evoked potential (SSEP). ${ }^{1,4}$ Studi yang menggunakan modalitas elektrofisiologi tersebut pada Sindrom Miller-Fisher masih terbatas sehingga butuh penelitian lanjutan untuk dapat disimpulkan dan beberapa hasil pemeriksaan sangat bergantung dari variasi klinis Sindrom Miller-Fisher. Contoh pada pemeriksaan blink reflex akan didapatkan abnormalitas gelombang R1 dan R2 pada pasien Sindrom Miller-Fisher yang mengalami paralisis wajah sementara hasilnya normal pada pasien Sindrom Miller-Fisher tanpa paralisis wajah. ${ }^{1}$

\section{Simpulan}

Beberapa temuan hasil elektrofisiologis yang konsisten dapat dijadikan petunjuk untuk menunjang diagnosis Sindrom Miller-Fisher. Pertama, abnormalitas konduksi saraf sensorik berupa penurunan amplitudo SNAP yang membaik dengan cepat tanpa tanda demielinisasi/remielinisasi pada pemeriksaan elektrofisiologi serial. Pemeriksaan elektrofisiologi serial dapat dilakukan mulai minggu kedua onset untuk melihat kecenderungan perbaikan dan minggu keempat onset untuk evaluasi hasil elektrofisiolgi ke nilai normal. Kedua, hilangnya gelombang $\mathrm{H}$ atau abnormalitas gelombang $\mathrm{H}$.

Dua poin temuan utama diatas dapat didukung dengan temuan hasil pemeriksaan parameter konduksi saraf motorik dan F-wave yang normal serta hasil pemeriksaan kecepatan hantar serabut saraf sensoris normal.

Terdapat beberapa poin keterbatasan studi yang meneliti gambaran elektrofisiologi dalam diagnosis Sindrom Miller-Fisher. Prevalensi Sindrom Miller-Fisher yang kecil pada populasi sehingga jumlah sampel pada penelitian jumlahnya sedikit. Tidak sedikit juga studi hanya 
berupa laporan kasus elektrofisiologi pada Sindrom Miller-Fisher. Hal kedua adalah spektrum klinis Sindrom Miller-Fisher bervariasi sehingga kriteria klinis yang dipakai untuk diagnosis Sindrom Miller-Fisher pada studi tersebut bervariasi.

Perbedaan teknik pemeriksaan elektrofisiologi juga menjadi salah satu faktor variabilitas hasil

\section{Daftar Rujukan}

1. Kuwabara S, Sekiguchi Y, Misawa S. Electrophysiology in Fisher syndrome. Clin. Neurophysiol. 2017;128,215-219.

2. Teener JW. Miller Fisher's Syndrome. Semin Neurol. 2012;1,512-516.

3. Yepishin IV, Allison RZ, Kaminskas DA. Miller Fisher Syndrome:A Case Report Highlighting Heterogeneity of Clinical Features and Focused Differential Diagnosis. Hawaii journal of medicine \& public health. 2016;75,196-199.

4. Arányi Z, Kovács T, Sipos I. Miller Fisher syndrome: Brief overview and update with a focus on electrophysiological findings. Eur. J. Neurol. 2012;19,15-20.

5. Hiu A, Wong $Y$, Yuki N. Miller Fisher syndrome is a nodo-paranodopathy, but not a myelinopathy. Future Neurol. 2015;10,15-24.

6. Lo YL. Clinical and immunological spectrum of the Miller Fisher syndrome. Muscle and Nerve. 2007;36,615-627.

7. Ito M, Kuwabara S, Odaka M. Bickerstaff's brainstem encephalitis and Fisher syndrome form a continuous spectrum: Clinical analysis of 581 cases. J. Neurol. 2008;255, 674-682.

8. Shahrizaila N, Goh K.J, Kokubun N. Serial nerve conduction studies provide insight into the pathophysiology of Guillain-Barré and Fisher syndromes. J. Neurol. Sci. 2011;309,26-30. studi elektrofisiologi pada Sindrom Miller-Fisher. Tidak ada standar yang sama mengenai saraf perifer yang diperiksa sehingga tidak dapat ditarik kesimpulan yang spesifik berdasarkan masing-masing saraf. Hal terakhir adalah perbedaan kriteria dalam menentukan abnormalitas parameter elektrofisiologi.

9. Shiga K., Tsuji Y, Fujii C. Demyelinating Features in Sensory Nerve Conduction in Fisher Syndrome. Intern. Med. 2012;51,2307-2312.

10. Sekiguchi Y, Misawa S, Shibuya K.. Clinical Neurophysiology Patterns of sensory nerve conduction abnormalities in Fisher syndrome: More predominant involvement of group la afferents than skin afferents. Clin. Neurophysiol. 2013;124,1465-1469.

11. Dachy B, Deltenre P, Deconinck N. The H reflex as a diagnostic tool for Miller Fisher syndrome in pediatric patients. J. Clin. Neurosci. 2010;17,410-411.

12. Umapathi T, Tan EY, Kokubun N. Nondemyelinating, reversible conduction failure in Fisher syndrome and related disorders. J Neurol Neurosurg Psychiatry. 2012;83:941-948.

13. Shahrizaila N, Goh K.J, Kokubun N. Sensory nerves are frequently involved in the spectrum of fisher syndrome. Muscle and Nerve. 2014;49,558-563.

14. Lyu RK., Chang KH, Chu CC. Sensory conduction study in fisher syndrome: Patterns of abnormalities and their clinical correlation. Eur. Neurol. 2013;70,27-32.

15. Uncini A, Kuwabara S. Nodopathies of the peripheral nerve: An emerging concept. J. Neurol. Neurosurg. Psychiatry. 2015.86,1186-1195. 